\title{
Administration, Interaction, and Identity in Lydia before the Persian Empire: A New Seal from Sardis
}

\author{
ELSPETH R. M. DusinberRe
}

\begin{abstract}
A stamp seal excavated at Sardis in 2011 is a local product dating to the period of the Lydian Kingdom. It was found in a churned-up deposit along with artifacts dating before the mid-6th century B.C.E., including a large proportion of high-status items: the seal itself and an ivory furniture inlay showing a female figure holding a lion upside down, as well as fine pottery, bronze arrowheads, a few scattered human bones, and other items. The deposit seems to be destruction debris from the Persian sack of the city in ca. 550 B.C.E. The seal is unique and is one of the only artifacts available to help us understand the administration of the Lydian Kingdom, to see what seal art looked like before the Persians arrived in Lydia, and to help us interpret the bureaucratic system and the cultural milieu of individual taste at Sardis in the Lydian period. A modest little seal thus has a great deal of importance in our analysis and interpretation of historical events, political developments, and society in general in Lydia during the years before 550 B.C.E.
\end{abstract}

Keywords: Lydia; Sardis; sealstone; griffin; lion; caprid; administration; cultural interaction; identity formation; pre-Achaemenid Anatolia

$\mathrm{T}$ he ancient city of Sardis in western Anatolia was the capital of the Lydian Kingdom and seat of its kings (Fig. 1). Excavation at the site has turned up evidence for domestic and monumental architecture alike, as well as for the activities of its denizens, but relatively little archaeological evidence has yet emerged concerning the elite residences and inhabitants of Sardis or administrative activities there. This is particularly true of the Lydian period between the Early Iron Age and the Achaemenid Persian conquest in the mid-6th century. It is interesting-even cautionary-that in this famous capital city, which has had the benefit of serious scholarly archaeological investigation through the decades, material evidence can be so hard to come by for major features of human behaviors and activities. However, a recent find at Sardis begins to shed light on the previously dusky area of Lydian administration and helps to add nuance to our understanding of what it meant to be

Elspeth R. M. Dusinberre: Classics Department, 248 UCB, University of Colorado, Boulder, CO 80309-0248; ermd@colorado.edu
Lydian - what kinds of cultural products or behaviors existed and had meaning in the context of Lydian Sardis before the Persians arrived.

One of the last days of excavation at Sardis during the field season of 2011 turned up an interesting find in a complicated context that helps to illuminate these questions. High on the slopes of the acropolis is a terrace created by a Lydian limestone terrace wall, which may have been the site of palatial or elite architecture (Figs. 2, 3). The terrace is known as Field 49, and a trench toward the southern end of the terrace produced a sealstone that provides virtually the only evidence excavated so far for the entire pre-Achaemenid administrative apparatus at Sardis during the time of the Lydian Kingdom. The seal has importance for what it suggests about life at Sardis during the reign of King Croesus, rich in gold; it is also significant as an excavated and datable artifact that may help to provide a chronological and cultural anchor for, as well as a correction to, those discussions of the past that have considered unexcavated, "floating," seals. ${ }^{1}$

\footnotetext{
${ }^{1}$ Christina Luke and Christopher Roosevelt have addressed some of these issues directly in Lydia itself (see, e.g., Roosevelt and Luke
} 2006a; 2006b; and Luke and Roosevelt 2009). 


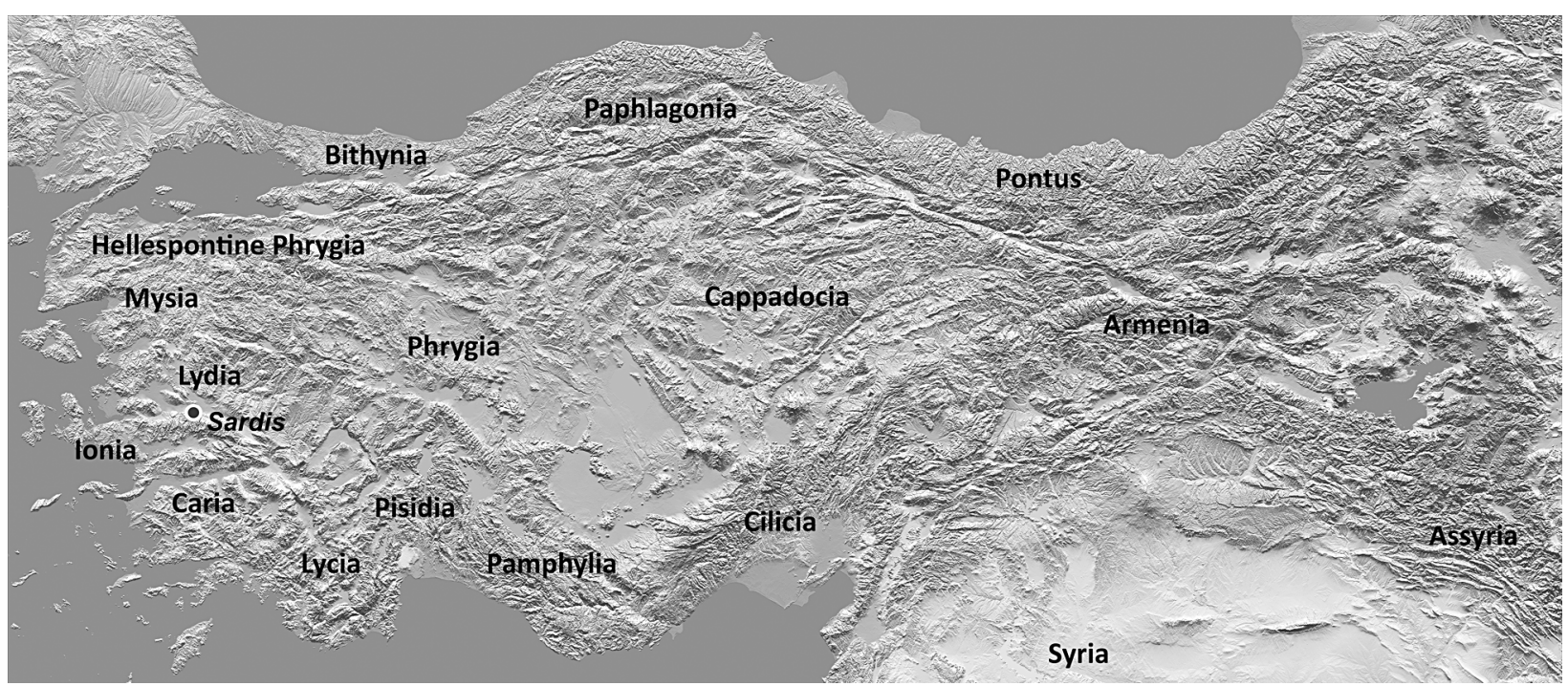

Fig. 1. Map of ancient Anatolia. (Courtesy of K. Mueller)

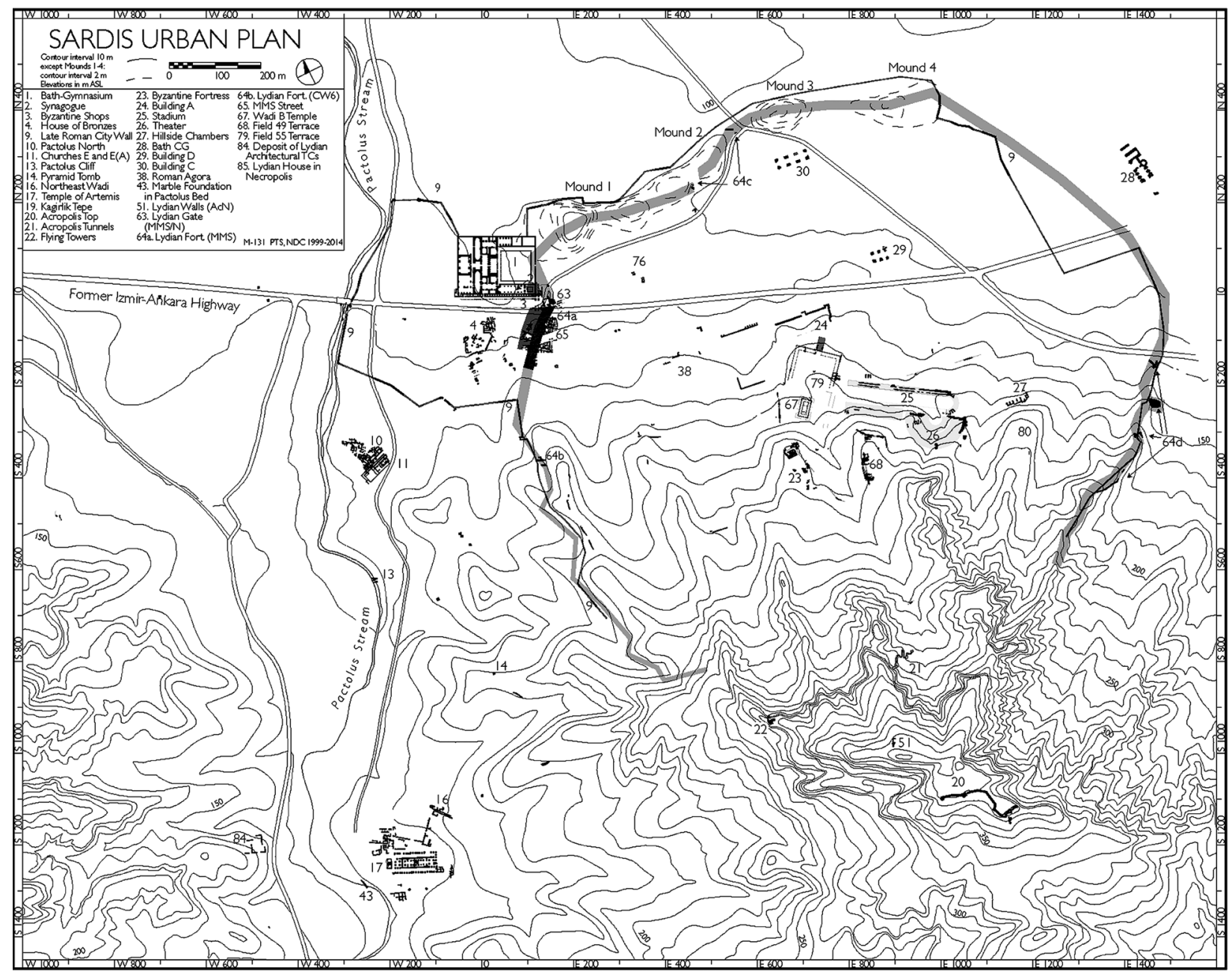

Fig. 2. Plan of Sardis. (๑ Archaeological Exploration of Sardis) 


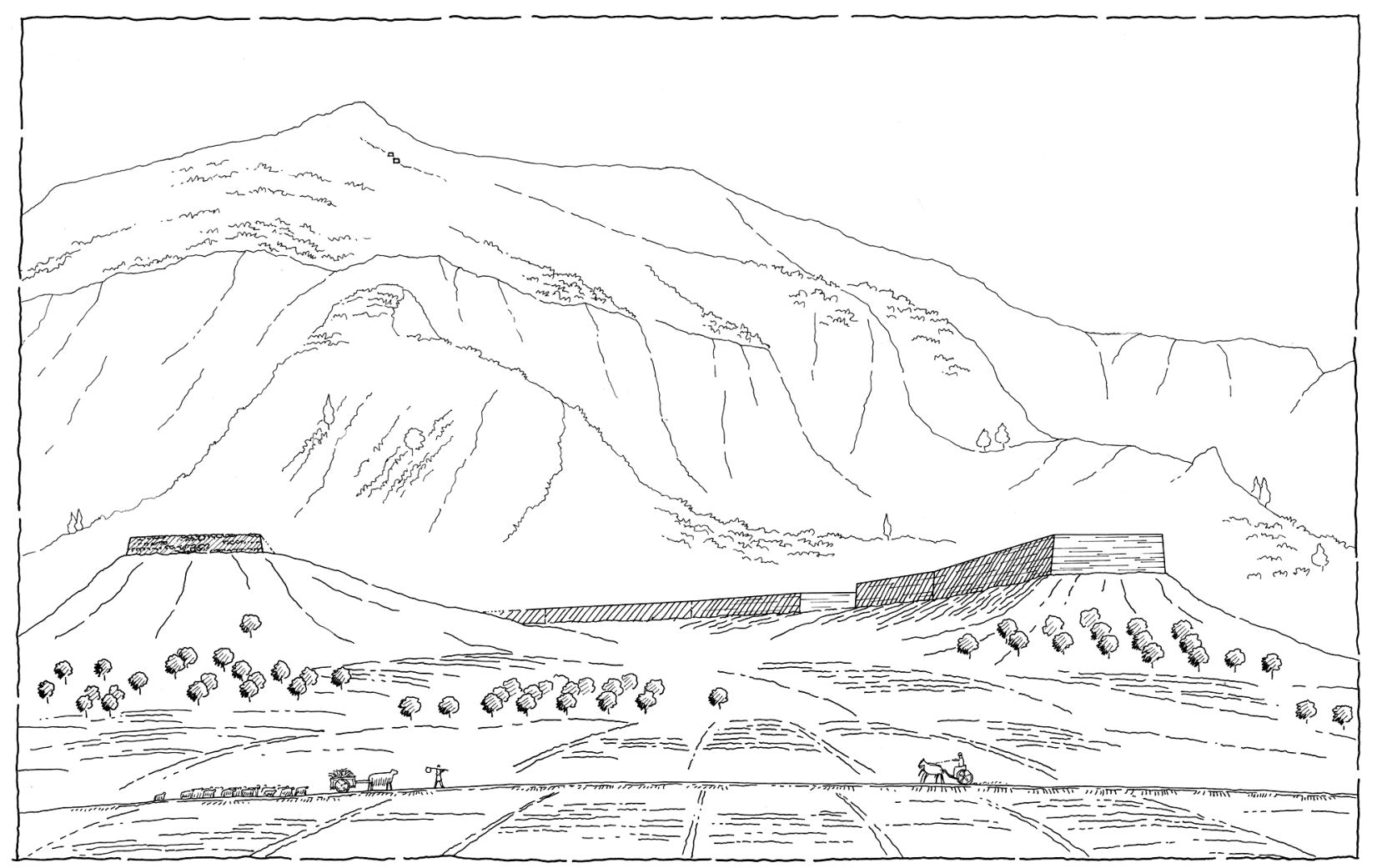

Fig. 3. Reconstruction of the terrace at Sardis. (Drawing by P. T. Stinson. (๑) Archaeological Exploration of Sardis)

\section{Archaeological Context}

The stamp seal (Manisa Museum 10937 [Sardis S11.014:12991]) is almost the only pre-Roman seal to have been found at Sardis during excavation of a nonmortuary context. ${ }^{2}$ It emerged from an archaeological context that included a few Hellenistic potsherds but was predominantly pre-Achaemenid Lydian in nature and date. The deposit was characterized by burned debris, including burned earth, mud brick, and vitrified mud plaster, as well as Lydian pottery of the 7th and early 6th centuries B.C.E., along with burned grain (subsequently identified as wheat) (Cahill 2013: 147; 2014: 126). The potsherds associated with the deposit illustrated in Figure 4 include four Lydian wild-goat-style fragments, two possible South Ionian Fikellura sherds, one Ephesian

${ }^{2}$ For the large number of important seals dating to the Achaemenid Persian period, all excavated from tombs, see Curtis 1925; and Dusinberre 1997; 2003; 2008; 2010a; 2010b; 2013. The other two examples of seals from non-mortuary contexts, both from Sector HoB near the Pactolus River, are a prehistoric stone stamp seal with a horned quadruped (Seal 66.001) (Hanfmann 1967: 29, fig. 15) and a terra-cotta stamp with linear devices from a mid-7th-century context (Seal 65.002) (Hanfmann 1966: 12-13, fig. 7). and one Ephesianizing sherd, one Attic Black Figure cup fragment, and at least one Ionian wild-goat-style fragment. Although the Fikellura style may have continued into the second half of the 6th century, it began in the first half; the other sherds are mid-6th century and earlier in date. ${ }^{3}$ One additional sherd of local gray ware from the

\footnotetext{
${ }^{3}$ I am grateful to one of the anonymous reviewers of this manuscript for observations concerning the identification and dates of the potsherds in Figure 4. For Lydian wares, see Gürtekin-Demir 2007; 2010; 2011; and Greenewalt 2010b. For Lydian wild-goat style, see Greenewalt 1970. For Attic wares at Sardis, see Ramage 1983; 1986; and Schaeffer, Ramage, and Greenewalt 1997. For Fikellura and early Fikellura wares at Sardis, see Greenewalt 1971. For Ephesian ware, see Greenewalt 1971; 1973; Cook and Dupont 1998; and Kerschner 2007. The Ephesian and Ephesianizing fragments here most closely resemble those in Greenewalt 1971: nos. 17, 18, 23, which he suggests date before 575 в.C.E. These sherds, like the other Lydian artifacts illustrated here, are from the same trench but not necessarily the same layer as the seal, a deposit that was disturbed as has been described. They, too, all come from disturbed destruction debris of the same nature as the seal, and Sardis project director Nicholas Cahill considers them useful in understanding the nature and date of the destruction debris with which the seal was associated.
} 


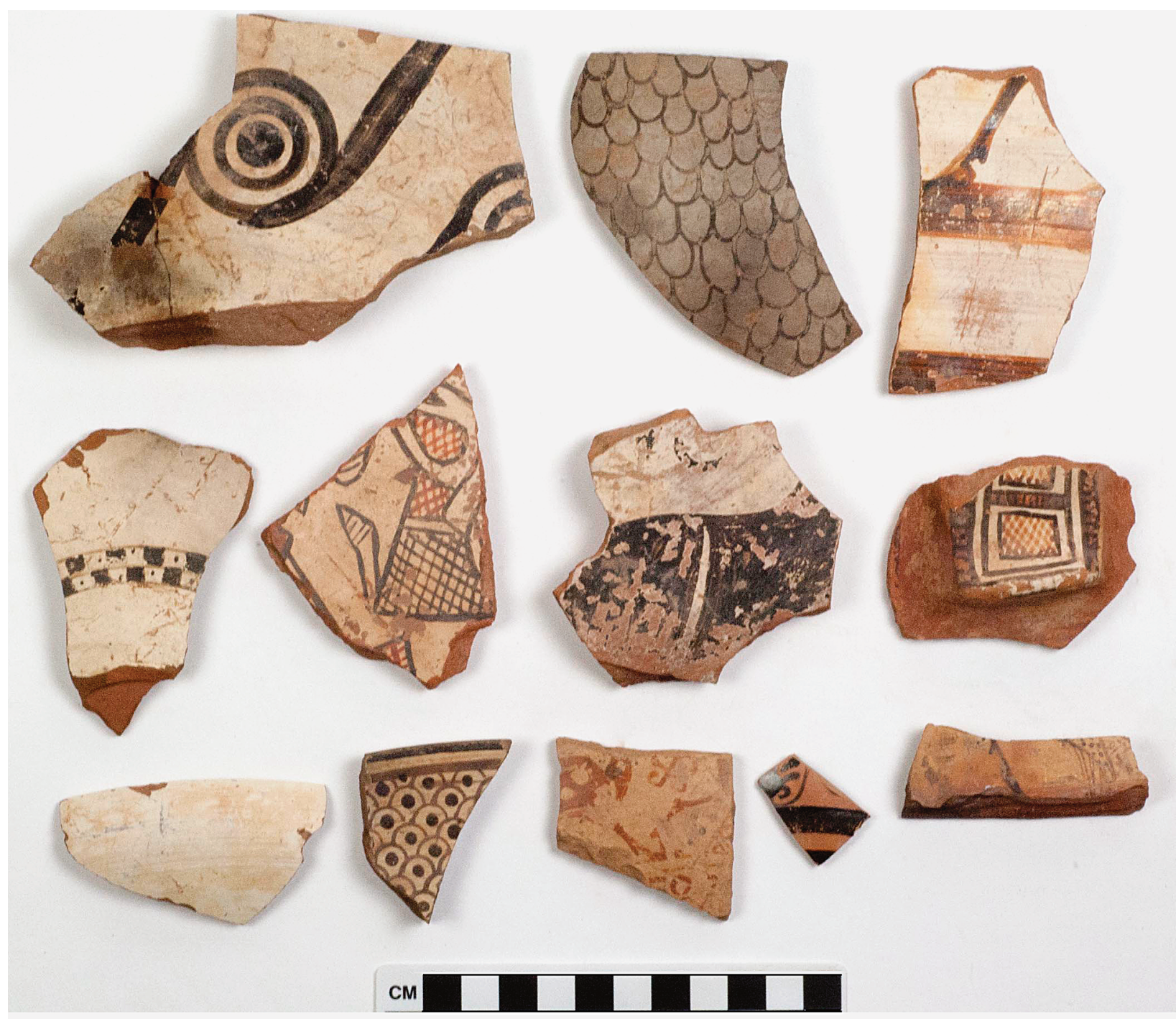

Fig. 4. Potsherds associated with the seal's (disturbed) context: Top row: P12.116:13153, P12.126:13177, P12.186:13273; middle row: P12.188:13280, P12.159:13231, P12.118:13155, P12.187:13278; and bottom row: P12.219:13326, P12.205:13306, P11.128:12993, P11.117:12882, P12.190:13282. (๔ Archaeological Exploration of Sardis)

deposit is embellished with appliqués designed to resemble Phrygian metalware bowls. ${ }^{4}$

Other finds associated with the context included valuable items: a bronze bowl, many two-flanged leaf-shaped bronze arrowheads (including two masses of at least 20 of them that had been heated so much as to melt them partially together into a fused lump [Fig. 5]), trilobate bronze arrowheads, a burned fragment of an ivory furniture ornamental plaque preserving the leg and foot of a figure wearing a skirt and the mane of an inverted lion, perhaps originally part of a "Mistress of the Animals" or

\footnotetext{
${ }^{4}$ For the phenomenon of Lydian clay imitations of Phrygian metalwork, see Gürtekin-Demir 2014.
}

animal control scene, and fragments of the same colorful stone from which the seal is made (Fig. 6). Sobering, and in keeping with the destruction debris from elsewhere at Sardis associated with the conquest of the city by the Achaemenid army in the 540s, was the discovery of various disarticulated and partial human bones as well (Cahill 2015: 420-41).

The context of the sealstone is not a closed one, nor an undisturbed one. Most of the artifacts associated with it, including the local pottery, date to the first half of the 6th century or earlier, however, and the nature of the deposit links it closely to the destruction levels associated with the domestic quarters of the site excavated farther down the slope of the acropolis, characterized by simi- 


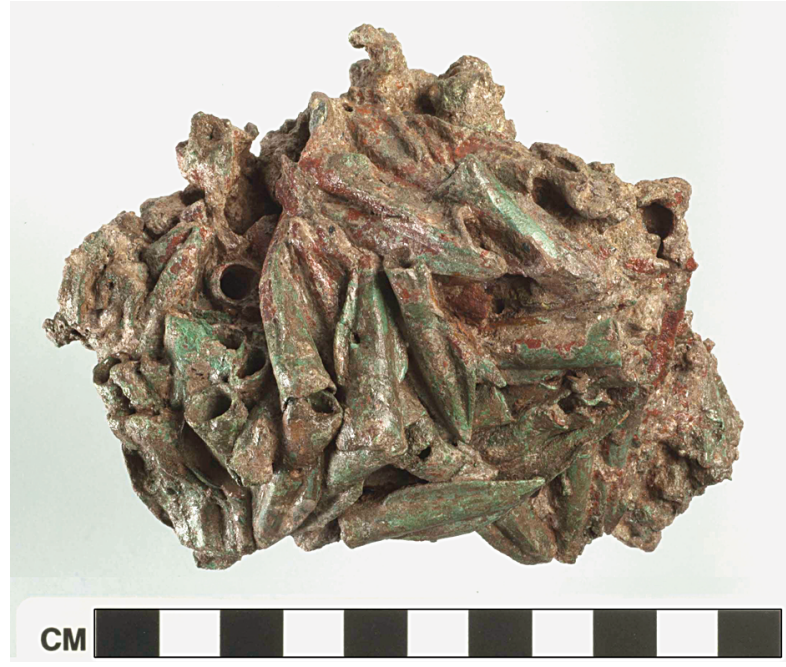

Fig. 5. Arrowheads associated with the seal's (disturbed) context (M13.015:13746). (@ Archaeological Exploration of Sardis)

lar bricky soil, burning, weapons, and early to mid-6thcentury pottery. ${ }^{5}$ Moreover, there is virtually no pottery or architecture from the hill that dates from the Achaemenid period, making it more likely that the context is pre-Achaemenid Lydian in date.

There are no precise comparanda for the seal, so this somewhat ambiguous stratigraphic context is the best clue to its date (Fig. 7). As we see below, however, that context, combined with various aspects of its form and apparent use, shows it was indeed a pre-Achaemenid local product (rather than, say, something that fell out of the pocket of one of the Persian invaders during the conquest of the city). Its date and context make it of particular interest and value in our growing understanding of Anatolian glyptics and Lydian Sardis.

\section{Sardis Seal S11.014:12991}

\section{Material and Suspension Device}

The seal is made of distinctive local jasper-cream with red veining - that comes from the area east of Sar-

${ }^{5}$ For the destruction level in the theater, see Greenewalt 2008: 375; 2009: 194-95; and Cahill 2010 (ed.): 64-65; 2011: 358-59; 2012: 212. For the Lydian houses in Sector MMS at Sardis, see Cahill 2000; 2005; 2010a; and the reports in the Bulletin of the American Schools of Oriental Research (Greenewalt et al. 1985; Greenewalt, Cahill, and Rautman 1988; Greenewalt, Rautman, and Cahill 1988; Greenewalt et al. 1990), as well as Greenewalt, Rautman, and Ratté 1995 (see also Greenewalt 1992).

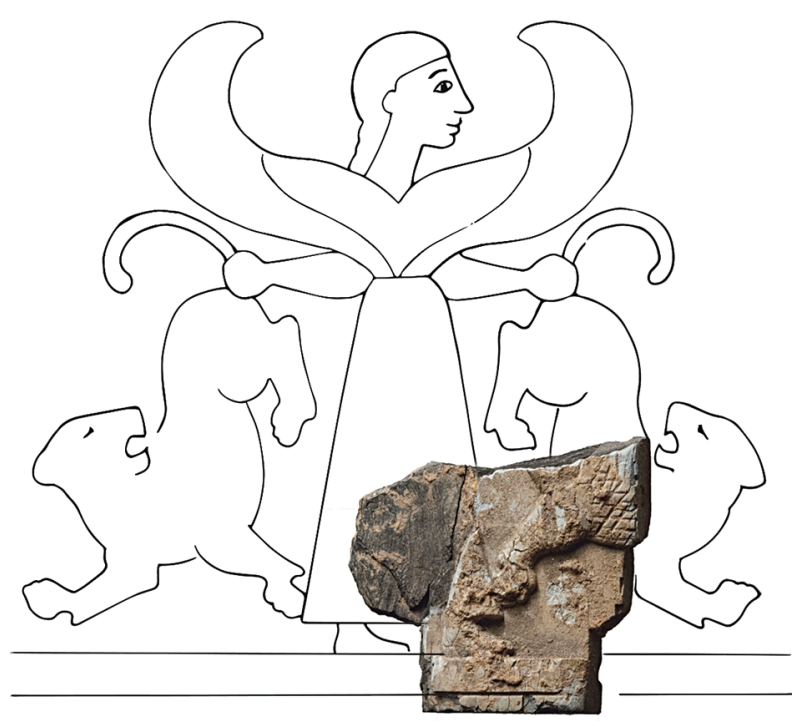

Fig. 6. Fragment of an ivory plaque associated with the seal's (disturbed) context (BI12.004:13117). (Drawing by C. Alexander. (c) Archaeological Exploration of Sardis)

dis, between Salihli and Güre (Figs. 7, 8). ${ }^{6}$ Its round, flat sealing surface is $0.12 \mathrm{~m}$ in diameter, its greatest diameter $0.16 \mathrm{~m}$, and its height $0.11 \mathrm{~m}$. The seal's diameter at its opposite side is greater than at its sealing surface; the opposite surface of the stone is gently arched to form what is sometimes called a "weight-shaped seal" (following Boardman 1970: 19, passim). Such a shape is not at all common in preserved excavated sealstones. Those few examples that have been excavated and thus may provide secure contexts and comparanda for the Sardis seal are from the Achaemenid period, from the sites of Gordion and Sardis itself.7 The two from Gordion are both carved from meerschaum and probably originated in the area

${ }^{6}$ C. H. Greenewalt, Jr., pers. comm. 1993, and see reference to 9 Eylül Üniversitesi Geology Faculty member Y. Savaş̧̧ın's comment that this stone is to be found in natural deposits between Salihli and Uşak (Özgen and Öztürk 1996: 130). A plate of the same jasper (AMM 75-10-66) was found at İkiztepe near Güre (see Özgen and Öztürk 1996: 130, no. 85). Bowls very closely resembling that one in shape and material were also found in the treasury at Persepolis (see Schmidt 1957: pl. 57, nos. 5-7; pl. 62 , nos. 5, 9, 11). Fragments of the same stone were also found in excavations at ByzFort at Sardis (N. D. Cahill, pers. comm., 2016).

${ }^{7}$ For Gordion, see Dusinberre 2003, cat. nos. 41, 42, which show a caprid with a vegetal element. Cat. no. 40 of white alabaster has a similar shape, with a loop handle carved of stone emerging from the back of the seal and hence quite different in how it would have felt to use. For Sardis, see Curtis 1925: nos. 121 (IAM 4523), 122 (IAM 4590). IAM 4523 is made of agate, with a heavy silver ring mounting on its back (somewhat akin to the Gordion alabaster seal), showing a lion and bull on its sealing surface, with a moon and solar symbol in the field. IAM 4590 is chalcedony, pierced for suspension, with a goat suckling a kid 


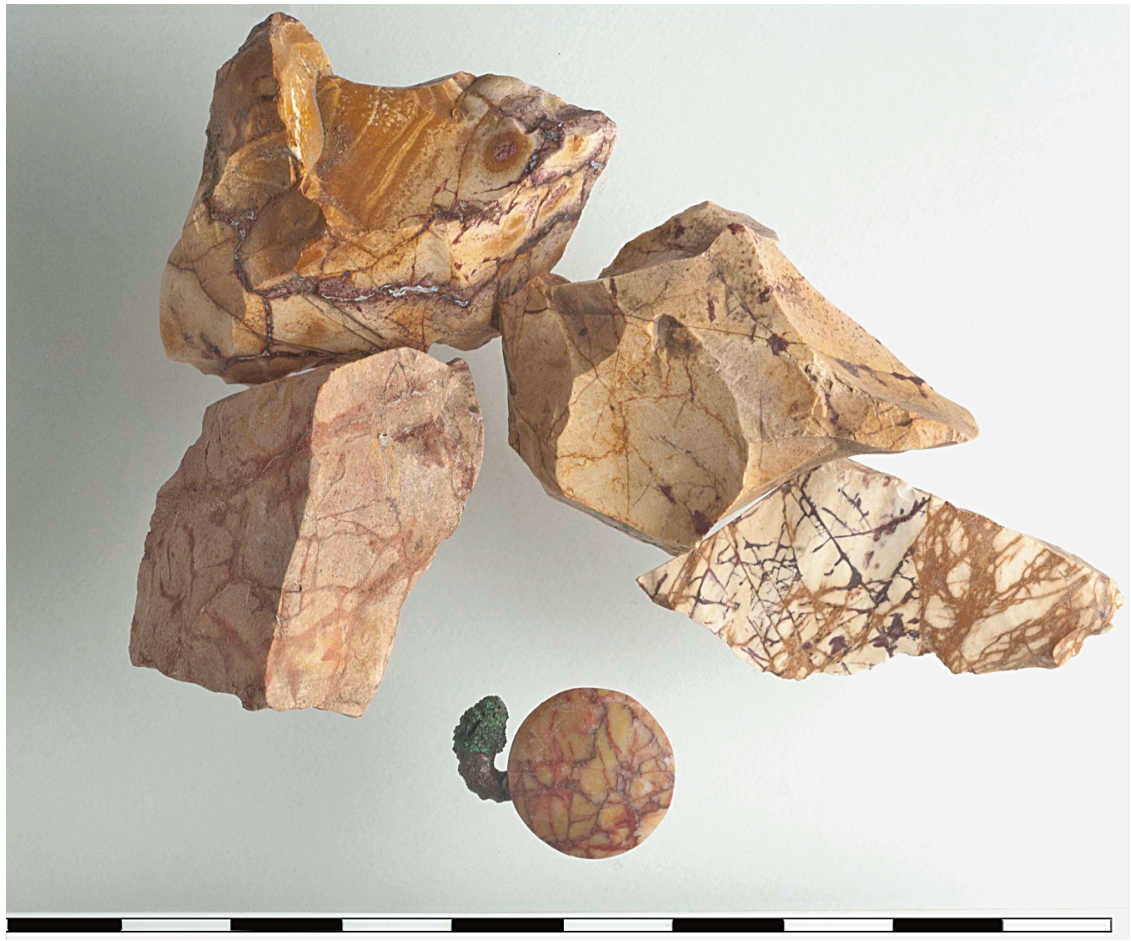

Fig. 7. Chunks of jasper associated with the seal's (disturbed) context. (๑ Archaeological Exploration of Sardis)

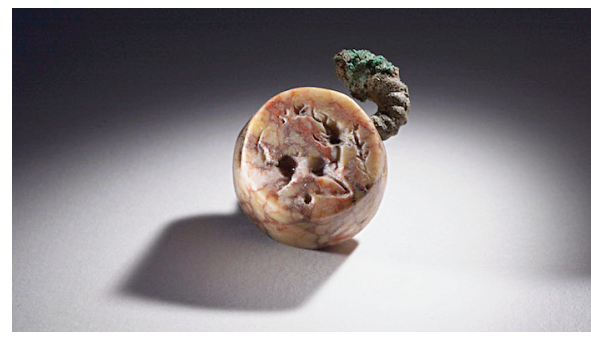

Fig. 8. Seal S11.014:12991. (@ Archaeological Exploration of Sardis)

around modern Eskişehir-thus, they came from northwestern Anatolia. It may perhaps be that this was indeed a seal shape in some way associated with this geographical region.

The seal was drilled through from both sides to meet in the middle, to form a hole for suspension; this drill hole is off-center, so the seal seems to have been intended

and a bird perched on her back (see also Dusinberre 2003: 274-76, fig. 93; 282-83, fig. 102. to hang as a pendant (Fig. 9). This suggestion receives additional support from the remains of a suspension device preserved in the form of a twisted double wire. The metal has been identified as bronze, although visual investigation suggests it may have had a high silver content. The suspension (made of two wires with slightly oval sections twisted around each other) is broken; it measures $0.025 \mathrm{~m}$ across where it enters the seal's suspension hole, and at its greatest thickness, swollen with weathering, it is $0.04 \mathrm{~m}$ in section. None of the Anatolian seal rings 

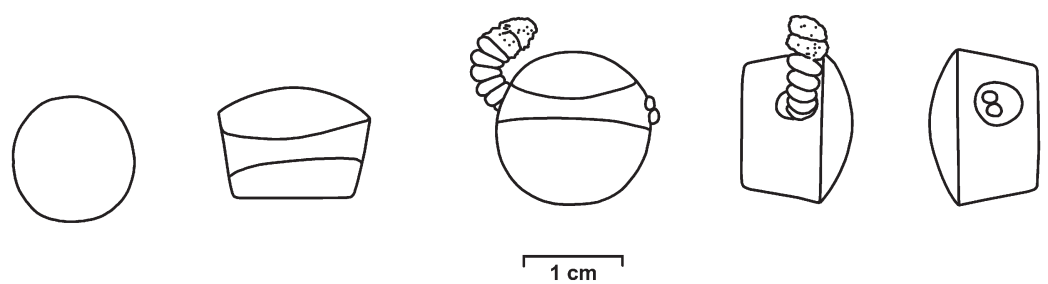

Fig. 9. Seal S11.014:12991. (Drawing by E. R. M. Dusinberre)

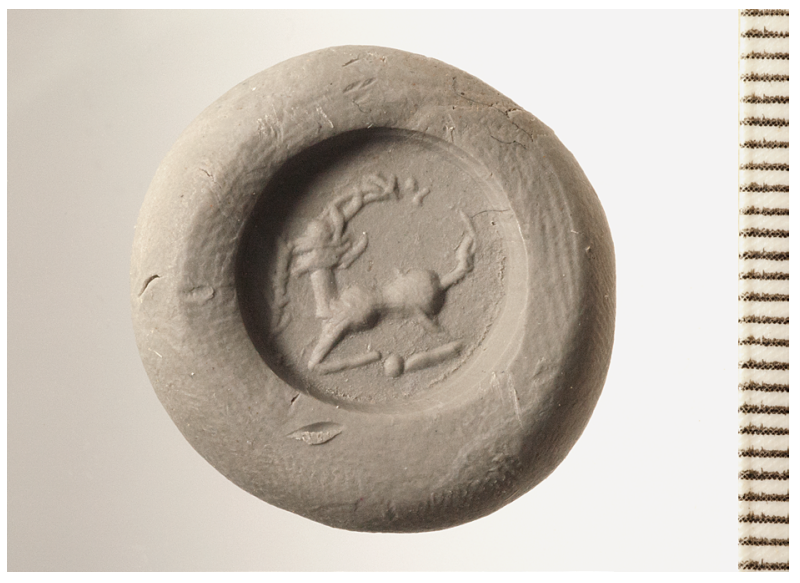

Fig. 10. Seal's impression. (๑ Archaeological Exploration of Sardis)

known to me from any period has a twisted wire band; indeed, it would be uncomfortable to wear. The nature of the Sardis seal's wire suspension and its off-center drilling make it most likely worn suspended from a cord or thong around the neck.

The hole is drilled in such a way that the stone would hang with its sealing surface oriented correctly up and down, so that if it were worn with the sealing surface facing out, another person would see the image on the seal from the correct vantage point. The seal's owner would have the advantage of knowing the seal's orientation, too, so that s/he could impress it on clay or wax without having to check its orientation first. In this way, the seal's perforation was strategically drilled to allow the seal to operate in a particular way, both as a displayed adornment meant to be read by those facing the wearer and as a functional social tool poised for deployment. Thus the off-centeredness of the drill-hole increases the immediate efficacy of the object as both adornment and tool. ${ }^{8}$

${ }^{8}$ The question of how stamp seals were worn is still waiting to be explored fully. There are no catalogs of Iron Age seals that systematically consider perforation holes or use-wear on suspension devices.

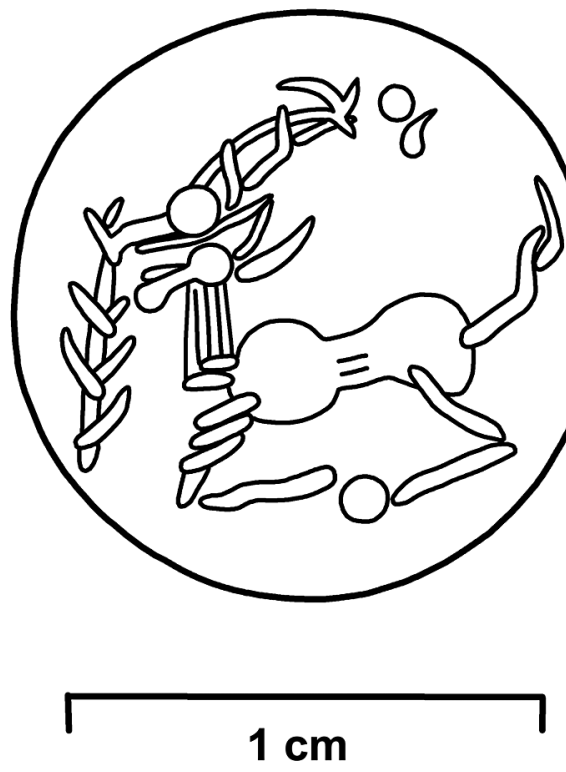

Fig. 11. Drawing of seal's impression. (Drawing by E. R. M. Dusinberre)

\section{Imagery}

Read as an impressed image, the sealing surface of the artifact shows a horned couchant quadruped facing left, with a vegetal element in front of it (Figs. 10, 11). The quadruped's body is formed of two, deeply drilled holes (on the left, basically round and, on the right, somewhat oval) connected by a deeply drilled cylinder. Its foreleg, bent beneath it, consists of one shallow, rather uneven groove for the lower part of the leg, while the upper part of the leg was initially marked by a single groove and then thickened using three parallel, short grooves. Its hind leg, also bent beneath it, consists of narrow lines for the upper and lower parts, the end of which culminates in a single round drill hole as a foot. Both legs overlap into the deeply

Such discussion is missing, for instance, from Collon 2001; this is an area of study with rich possibilities for future investigation. 
drilled holes of the body. The creature's tail is made of two crooked lines extending upward that create a wavy, almost flame-like appendage. Its neck, slightly narrower at the top than the bottom, was made by four vertical parallel lines carved shallowly with a running drill, finished at the bottom with two short horizontal lines.

Wear makes for a slightly unclear understanding of the shape of the creature's head. It consists of a rather deep, large hole for an eye and another slightly smaller one indicating the back of the jawbone; lines stretch from those holes to the left to form the upper and lower jaws of the creature's open mouth. Due to wear, the end of the nose has blended with the plant and is hard to see. It is possible that the nose bends down to create a hooked beak, with a small tripartite extrusion at the curve of the beak resembling a spike or spiky lotus. Another understanding is that the upper jaw ends in a blunt nose like a lion's, and the plant originally extended up a little farther, to culminate in a spike above and in front of the animal's nose. The animal's upper jaw is thickened with another very narrow line, and a tongue is indicated at the lower jaw. At the back of the quadruped's head are two shallow striations and a third curved line that lend additional flame-like effects to the creature's appearance; they may be intended to represent ears, a mane, or perhaps both.

The quadruped's horn is curved like that of a wild goat or ibex; its upper edge is indicated with a single arching line, and its segments are formed by drawing the groove that forms the lower edge of the horn up to the top several times. The horn is worn at its tip; the exact nature of the additional lines at its tip is unclear. Two small symbols after the end of the horn may originally have connected to it or may have been separate elements, a dot and a comma-like shape, from its inception.

The Creature Has No Wings.

The vegetal element in front of the quadruped is created via a vertical line with diagonal strokes carved up and away from it on both sides to indicate long, narrow leaves. Such spiny foliage has a very long history in Near Eastern (including Anatolian) glyptic art and is normal shorthand for a plant of indeterminate type, particularly on stamp seals (see below).

The sealstone is worn. This is particularly evident around the edges of the suspension hole and the circumference of the sealing surface, but it is also obvious on the sealing surface itself (as already noted). This is a fact of real interest and significance. It means the seal was not freshly carved at the time of its deposition.

\section{A Lydian Seal}

The fact that this seal is made of a distinctive local stone and was significantly worn before deposition makes it unlikely that it belonged to a foreign invader. Its shape is one that may conceivably be associated with the geographical region of western Anatolia. Its twisted-wire suspension device is of a sort not preserved in glyptics from elsewhere. It was thus probably made nearby and had seen considerable use before it was dropped. This is significant.

If this seal was a local production crafted before the Achaemenid period, it is the only one known at this time-the only securely pre-Persian Lydian sealstone. Indeed, aside from coins, it is the only piece of elite administrative equipment found at Sardis from the decades preceding the Achaemenid conquest-the only evidence suggesting personal accountability as well as government-organized bureaucracy in the Lydian Kingdom. When considered within the broader context of seal usage and glyptic culture in Anatolia in the early 6th century and the iconographic possibilities of Anatolia, Syria, and the Aegean, it provides a fascinating glimpse of intercultural interactions between Lydia and the greater world.

Once again, Gordion may provide useful comparative information to help us understand the administration and shifts in administrative practices in the subsequent Achaemenid period. ${ }^{9}$ There, a significant increase in the number of seals and the variety of iconography is seen in the Achaemenid period as compared with the earlier Middle Phrygian period. So far, the evidence from Sardis suggests a similar development: A large number of Achaemenid-period seals carved of semiprecious stones with varied imagery have been excavated from tombs at the site. At this point, it is too early to be sure if the apparent change at Sardis might not be due to something other than a change in administrative practices-for instance, a change in mortuary customs during the Achaemenid period that caused people to be buried with their seals where previously they had not. The discovery of this Lydian seal at Sardis suggests that administration at the site may not have changed as radically as previously believed, however. Its imagery helps us to contextualize not only the seal but also Lydian culture and visual expression before the Achaemenid period.

\section{Setting the Seal in Its Cultural Context}

There are no close parallels for this seal's imagery. Although the creature at first glance resembles a goat or

\footnotetext{
${ }^{9}$ For the shift in seal usage in Phrygia with the arrival of the Persians and the imposition of Achaemenid imperium, see Dusinberre 2005. For the seals from Sardis, see esp. Dusinberre 2003. For a comparison between the two, see Dusinberre 2010a. For the remains of an Achaemenid archive excavated at the satrapal site of Daskyleion, see Kaptan 2002.
} 
even a deer, close examination shows it is a Mischwesen, a fabulous hybrid beast of some sort. As mentioned, the wear at the top of the vegetal element makes it hard to be completely certain whether the creature has a lion's head or the head of a bird of prey with curved beak. Both lions and birds of prey were symbols of the Phrygian goddess Kybele, who, along with Artemis, seems to have enjoyed prominent favor and worship at Sardis during the Lydian period..$^{10}$ Either way, however, the combination of caprid horn with lion or bird head, indeterminate animal's body, no wings, and flame-like tail finds no parallel in extant glyptics or any other art. This seal is unique in its iconography.

Its style is also otherwise unparalleled. Although the use of an outline to draw the ibex horn is known from Early Phrygian Gordion, the particular manner of drawing it by using a simple arched line to form the top outline of the horn and then a series of upturned lines almost like a guilloche to form the bottom outline and segments of the horn is not found in any other portrayal of goat horns known to me. ${ }^{11}$ The combination of very deep drilling, especially to form the fore- and hind parts of the creature's body, with very shallow-almost tentative-lines to indicate its legs, horn, and other details, is also most unusual. The use of juxtaposed parallel lines to thicken a body part and (perhaps) indicate musculature, as in the upper part of the creature's foreleg and the neck, is also not common, although there are Phrygian relief sculptures that use a series of parallel lines in the neck of a fabulous beast (Fig. 12). ${ }^{12}$ Overall, however, there are no parallels for the seal's style or iconography.

Nonetheless and significantly, the seal fits into a very complex scenario of cultural and iconographic interactions that help to contextualize not only its manufacture but also what it meant to live in Lydia in the first part of the 6th century в.C.E. One of the defining features of the Sardis seal's imagery is the great curving horn of the wild goat that springs from the creature's head. Goats were favored images on stamp seals of the mid-1st millennium B.C.E. The combination of goat and vegetal element is common in stamp seals of the Near East during the 1st millennium (particularly during the latter two-

\footnotetext{
${ }^{10}$ For this goddess and her importance in Lydia, see, e.g., Rein 1993. Associations between lions and birds of prey are very well attested in Phrygia. For a whimsical example, see Roller 2009: no. 96. The frequent portrayal in Phrygia of animals associated with the cult of the Phrygian Mother (lions, birds of prey, and mixed creatures) is probably connected to her character as a goddess of power and protection (Collins 2002: 332).

11 Early Phrygian ibex horns indicated with lines are illustrated in Roller 2009: nos. 72, 73.

12 E.g., at Kerkenes Dağı (see Draycott and Summers 2008: cat. no. 3.6 , pls. $29,35,94)$.
}

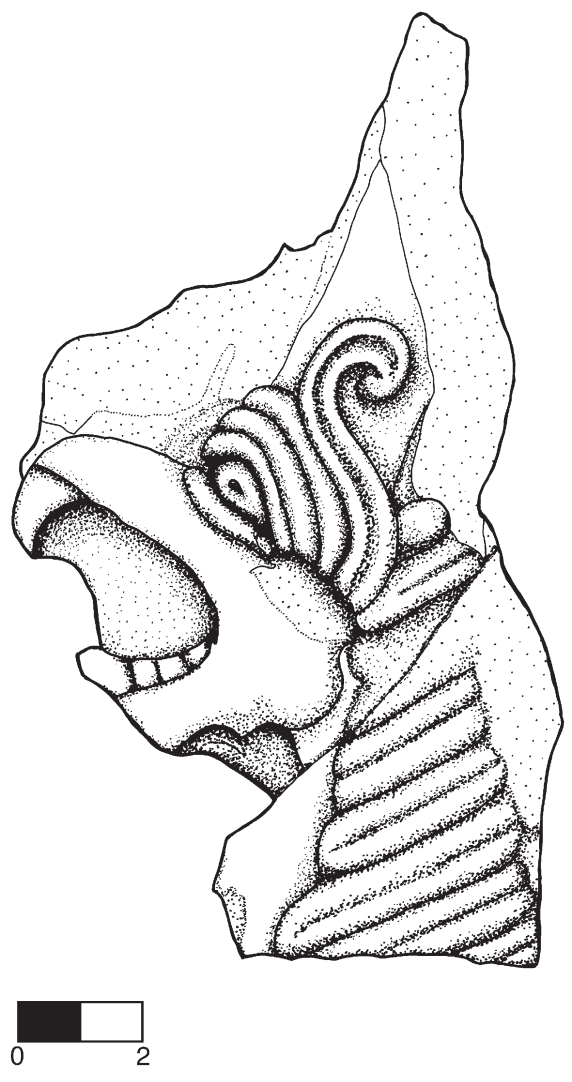

Fig. 12. Fragment of a griffin's head from Kerkenes Dağı (after Draycott and Summers 2008: pl. 35). (Courtesy of The Oriental Institute of The University of Chicago)

thirds). ${ }^{13}$ Such caprids in seal art are usually walking rather than couchant, unlike the Sardis seal's image. The most common symbol associated with goats in glyptics is

${ }^{13}$ Because this seal is unique in iconography and style, I have branched out slightly from my normal practice; although I focus here on excavated examples of ancient sealstones and seal impressions, I have also combed through catalogs of collections that include artifacts acquired long ago on the art market. I have not considered artifacts not in compliance with the UNESCO agreement. Examples of goats associated with vegetal elements abound and are far too numerous to list here (for a few typical specimens, see, e.g., Schachner 2014: fig. 9:3; and Reyes 2001: cat. nos. 194, 196, 198). The largest corpus of mid-1st-millennium glyptic art is found in the form of seal impressions in the Persepolis Fortification Archive, dating to around 500 B.C.E. Of the more than 3,400 discrete legible seals represented in the Fortification Archive, 88 are stamp seals with a single animal. Of these, at least three and possibly five are stamp seals showing a single caprid with spiky vegetation. I am grateful to Mark B. Garrison for permission to include the Persepolis Fortification Archive seals in this discussion. Earlier examples of wild goats and vegetation include Matthews 1990: nos. 217, 221, 321, 322, 323; and Mitchell and Searight 2007: nos. 66 (?), 89. For an overview of the ibex's significance and the birds of prey with which it was frequently associated in Near Eastern art, see Root 2002: 184-92. 


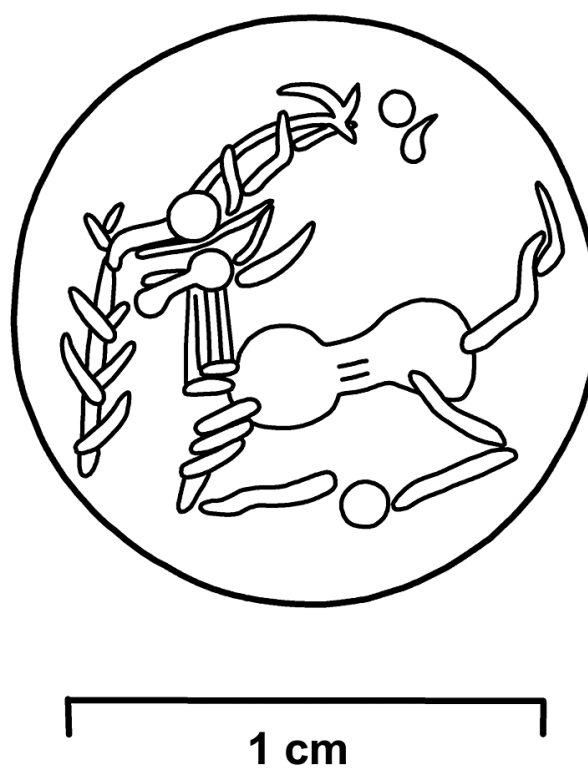

Fig. 13. Seal impression with bird's head. (Drawing by E. R. M. Dusinberre)

a crescent (or sometimes full) moon; however, still more numerous examples of stamp seals dating to the middle of the millennium display a single caprid devoid of an accompanying object. ${ }^{14}$ Thus the lack of such a symbol in the field of the Sardis seal is a well-documented characteristic. Similarly, the combination of a goat-like creature

${ }^{14}$ For instance, the Persepolis Fortification Archive includes at least 39 examples of a single caprid on a stamp seal (walking or couchant), and at least 14 examples of a caprid with a moon. Caprids in the Fortification Archive stamp seals are also represented with birds (three) and stars (three or possibly four). The ibex figures on four of these stamp seals (PFS 283s, PFS 1207s, PFS 1292s, and PFS 1512s) will be published in Garrison and Root forthcoming. The association of a goat with the moon has its roots in earlier periods, however; a composite scaraboid excavated from a domestic context at Assur has an ibex on one side and a crescent moon on a stand on the other (Jakob-Rost 1997: no. 368), while other Assyrian stamp seals show an ibex with the moon (Jakob-Rost 1997: nos. 360, 365, 369, 371 from Assur, 364 from Babylon; Mitchell and Searight 2007: nos. 78, 89), a star (Jakob-Rost 1997: nos. 361, 366, 367, 370 from Assur; Keel-Leu 1991: no. 140), vegetation (Jakob-Rost 1997: nos. 363, 365, 369 from Assur, 372 from Babylon), and a bird (Jakob-Rost 1997: no. 371 from Assur). The single wild goat on a stamp seal is known in at least one example of an impression on a tablet from Kuyunjik (Mitchell and Searight 2007: no. 175) and reached the glyptic art of the steppes, too (see Francfort 2013: no. 25, fig. 42). A goat associated with a bird-headed griffin appears on a Syrian seal published in Jakob-Rost 1997: no. 121. Similar associations are to be found on much earlier cylinder seals as well (see, e.g., Matthews 1990: $221,324,325)$. with spiny vegetation also links the seal to patterns and iconography known elsewhere as well.

If the Sardis seal creature has a bird's beak, it finds itself in good company but with no precise parallels. Birdheaded, lion- or human-bodied deities are well known from Assyrian and Phrygian relief sculpture-where, however, they lack horns and have wings (Fig. 13). ${ }^{15}$ Bird-headed, winged, lion-bodied creatures were certainly known in western Anatolia in the middle of the 6th century, as an architectural terra-cotta from Düver shows (Özgen and Öztürk 1996: fig. 26; see also Mayo 1981 and Buzzi 1999). But the creature's multicolored wing and sharp, straight-horn-like ear distinguish it from that of the Sardis seal (see, e.g., Özgen and Öztürk 1996: fig. 26). ${ }^{16}$ Other Lydian architectural terra-cottas show a similar approach to rendering winged, bird-headed griffins, usually with a knob protruding from their foreheads (see, e.g., Ramage 1978: nos. 15, 16, 17; and Hostetter 1994: figs. 38 , 47). The bird-headed griffin is tremendously popular in wild-goat-style pottery as well as in the bronze cauldron attachments of the archaic period. The painted ones are usually shown with a protrusion from the beak or forehead in the form of a knob; the bronze heads attached to cauldrons also have a spiky, knob-like protrusion jutting from their foreheads. ${ }^{17}$

${ }^{15}$ For Phrygian examples, see, e.g., Prayon 1987: 28, pl. 10; Draycott and Summers 2008: pls. 79c, 81b; and Orthmann 1971: pl. 26d.

Readers may think that Figure $\mathbf{1 3}$ is identical to Figure 11 and the following Figure 15; in fact, each is different. Note the interface between the upper jaw (the nose) of the creature and the top of the plant; it is the only difference. I cannot tell if it is intended to be a short, straight upper jaw (like a lion) or a curved, pointed beak (like a birdheaded griffin). So, this part of the first drawing is ambiguous, while the second one is a beak, and the third one a truncation.

${ }^{16}$ This is a creature with a very long history in the Near East (see, e.g., Matthews 1990: no. 210).

17 The only example of a wingless bird-headed griffin known to me is on an unprovenanced seal published in Wagner and Boardman 2003: no. 23. A splendid winged, bird-headed griffin on an ivory comb was excavated at Gordion (see Prayon 1987: no. 177; and Young 1956: 257, pl. 86, 23). An ivory, winged, bird-headed griffin excavated from the Artemision at Ephesus is illustrated in Fitton 1992; pls. 6c, d, 7a-d; it was accompanied by an ivory ibex illustrated on pl. 8a. Examples of winged, bird-headed griffins in wild-goat-style paintings are, again, far too numerous to list exhaustively, but a few examples can be found in Kardara 1963: pls. 4, 12; Walter-Karydi 1973: pl. 50, no. 445; pl. 66, no. 517; pl. 78, no. 646; pl. 83, no. 616; pl. 112, no. 949; pl. 115, no. 942; pl. 116, no. 952; and Cook and Dupont 1998: 41, fig. 8.9. They are not very common in local Lydian wild-goat-style pottery, but those examples excavated at Sardis are illustrated in Greenewalt 1970: pl. 14, figs. 1-3; pl. 17, fig. 1. Bird-headed-griffin cauldron attachments are collected in Jantzen 1955 and Herrmann 1979. These remarkable creatures usually have a long, almost snaky neck, often with long, curling locks like those of the Lydian delegation on the Apadana reliefs at Persepolis and/or scaly feathers, long, sharply pointed ears, and an open mouth with a tongue clearly indicated. Most have a knob on the forehead. None has 


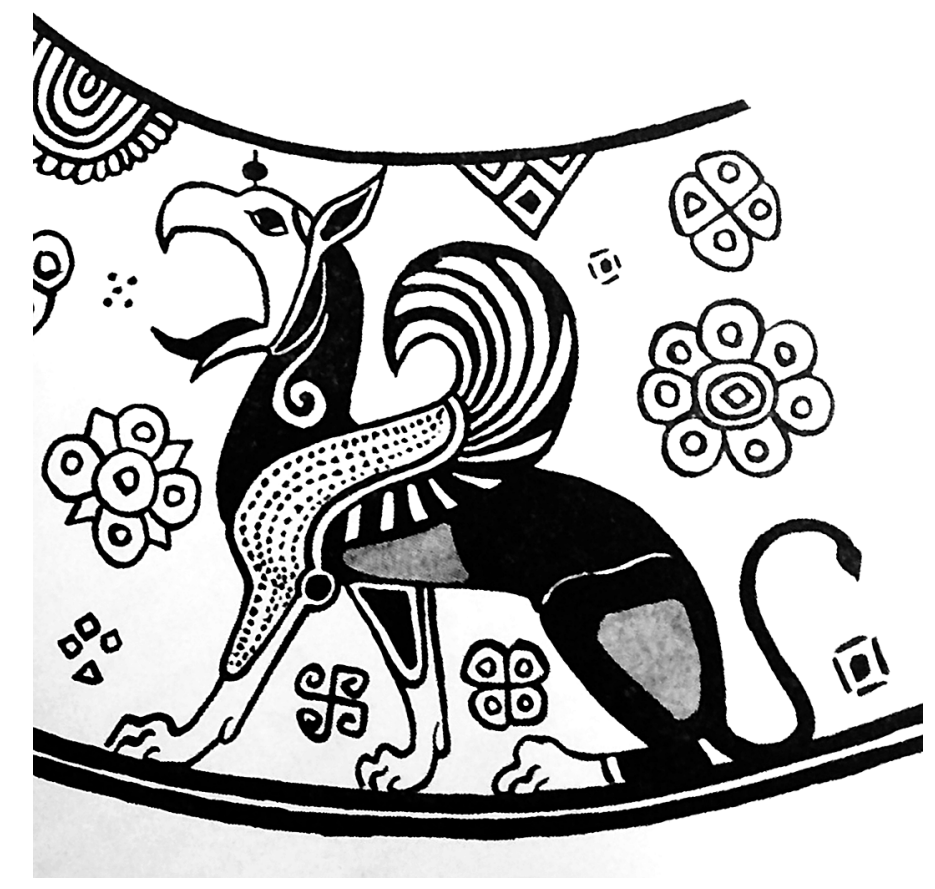

Fig. 14. Wild-goat-style painted griffin (Munich 449) (Drawing by E. R. M. Dusinberre, after Walter-Karydi 1968: fig. 2).

Unlike the seal from Sardis, the bird-headed griffins I have cited are all winged (when they have bodies). The only bird-headed griffin with goat horns known to me is preserved as an impression on a bulla found as part of a hoard or cache of sealings from a Hellenistic grave at Ur. That example shows an elaborate predatory bird's head with a flame-like mane and a small, intricately twisted goat's horn (Legrain 1951: 51, pl. 41 no. 783; Collon 1993:

ibex horns, although Ulf Jantzen (1955: pl. 47, nos. 4-6) demonstrates that wild goats could themselves occasionally function as cauldron attachments. A similar griffin's head is rendered on electrum coins of Phokaia (Weidauer 1975: no. 179; Bodenstedt 1981: pl. 44, no. 22); and electrum coins minted in Ionia (?) on the Phoenician standard perhaps in the 7th and 6th centuries also have the heads of bird-headed griffins on them (Head 1964a: pl. 1, nos 15, 16-but note that even the author describes these coins as "unattributed and doubtful"). The winged, bird-headed, knobby-foreheaded griffin was picked up again in the coinage of Teos in the 5th century (see Kraay 1976: nos. 893, 894, 895). There are at least 13 examples of a hero figure controlling a birdheaded, lion-bodied creature on the seal impressions of the Persepolis Fortification Archive, and at least eight examples of such a creature alone on a stamp seal. The figure's popularity in Achaemenid times is shown also in the bird-headed-griffin mold from the palace at Chorasmia (Francfort 2013: fig. 83). Caprids are occasionally represented with birds in glyptic art; an example of a bird-ibex Mischwesen can be found in Herbordt 1992: pl. 15 no. 22 (with a crescent moon and vegetal element). Its Assyrian antecedents in glyptic art are demonstrated in, e.g., Matthews 1990: no. 423.
74, pl. 20; Mitchell and Searight 2007: no. 539) (Fig. 14). Thus, although bird-headed griffins are very common, they do not provide good parallels to the Sardis seal.

If the Sardis seal creature has a lion's head, then it is no easier to find good comparanda. Winged lions form an important part of Neo-Hittite, as well as Phrygian, iconography. ${ }^{18}$ The lion-headed griffins of glyptic art and sculpture all have wings (Figs. 15, 16); although many sport horns, they are not the great crested affairs of the wild goat. ${ }^{19}$

The square-jawed lions of Urartu and Phrygia or the electrum "walwet" or "croeseid" coins of 6th-century Lydia do not resemble this creature (Fig. 17). ${ }^{20}$ Lions

\footnotetext{
${ }^{18}$ For a Phrygian example, see, e.g., Prayon 1987: 22, pl. 7b; and Draycott and Summers 2008: pl. 80a.

${ }^{19}$ For an example from Zincirli (described as "Phoenician"), see Jakob-Rost 1997: no. 171. Numerous examples of short-horned liongriffins are to be found in the Persepolis Fortification Archive, but none with ibex horns. For an early association between lions and goats excavated in Anatolia, see Collins 2002: fig. 11.3, showing a sealed tablet from Kültepe with a goddess seated on a goat over two lions.

${ }^{20}$ For a (probably) Urartian example, see Herrmann 1979: pl. 34. For Phrygian square-jawed lions, see, e.g., Roller 2009: figs. 19, 20. A snarling lion with indeterminate jaw shape is illustrated in Draycott and Summers 2008: cat. no. 3.9, pl. 37. For the lions of excavated Lydian coinage contemporary with the Sardis seal, see, e.g., Kroll 2010: 417-18, nos. 17-21; and Cahill and Kroll 2005. For electrum Lydian
} 


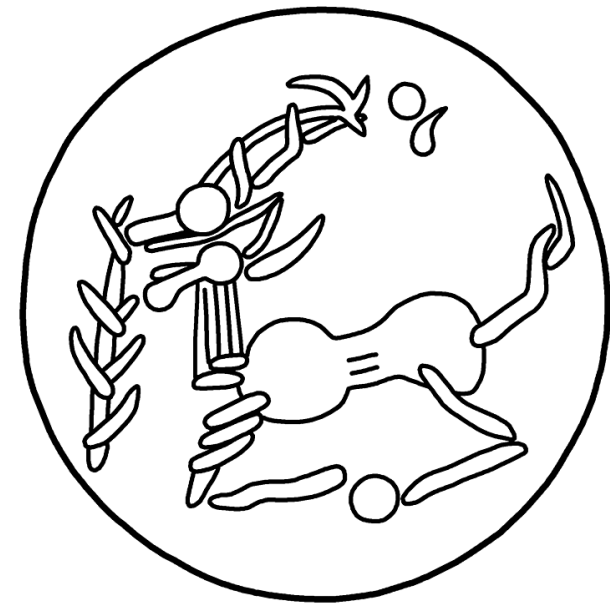

\section{$1 \mathrm{~cm}$}

Fig. 15. Seal impression with lion's head. (Drawing by E. R. M. Dusinberre)

with enormous fanciful antlers are known from Scythian contexts, but not with the horns of the ibex (see, e.g., Francfort 2013: fig. 30b [from Tuekta in the Altai], 30c [from Aluchaideng]). But the association of lions with wild goats is common on West Anatolian painted pottery of the 6th century, as is the combination of unlikely elements into new fabulous creatures, so it should not be surprising to find such a combination here (if such it is). ${ }^{21}$

The manner in which the Sardis seal's horn is drawn is unique, to my knowledge. ${ }^{22}$ Interestingly, perhaps the

coins excavated at Gordion, see Kroll 2010: no. 24; Young 1964: 283, fig. 13; Bellinger 1968; Weidauer 1975: no. 104; and Wallace 2006: 40. Additional pre-Croeseid Lydian electrum coins with square-jawed lions are illustrated in Head 1964b: pl. 1, nos. 1-13. For square-jawed lions on Achaemenid-period seals from Sardis, see Dusinberre 2010b: figs. 7, 8, 9 .

${ }^{21}$ For lions and goats or splendidly horned goat heads in isolation amid animals of various types, see, e.g., Walter-Karydi 1973: pl. 23, no. 187; pl. 90, no. 715; pl. 111, no. 879; pl. 114, no. 938. For the surprising combination of a hare's head with a human body, see Walter-Karydi 1973: pl. 72, no. 549. The association of goats and birds of prey is not found in West Anatolian painted pottery, although the prevalence of water fowl on these pots means there are various examples of goats and water birds found together (see, e.g., Walter-Karydi 1973: pl. 67, no. 513).

${ }^{22}$ A few archaic electrum coins of Phokaia include goats, the horns of which are indicated by a deep, long groove with small drill holes at the upper edge, each drawn down into the horn with a small line that intersects the horn a little (Bodenstedt 1981: pl. 2 no. 7; pl. 44). In this way, they resemble the horn illustrated here on IAM 4641. I am grateful to John Nebel for bringing this to my attention. Intriguingly, one of these dies shows a goat with a plant in front of it-an example of a

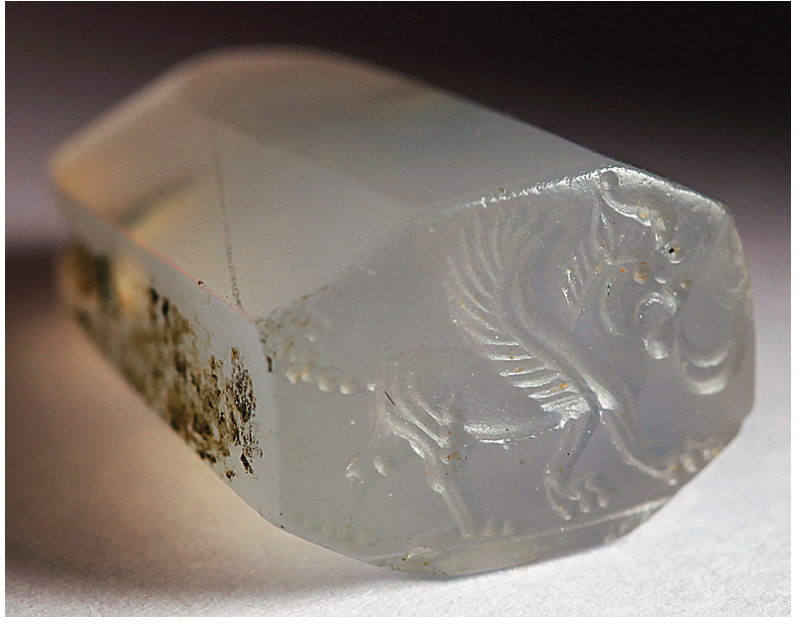

Fig. 16. Lion-griffin, on an Achaemenid seal from Sardis (IAM 4528). (Courtesy of Yapı Kredi Bankası, Vedat Nedim Tör Müzesi)

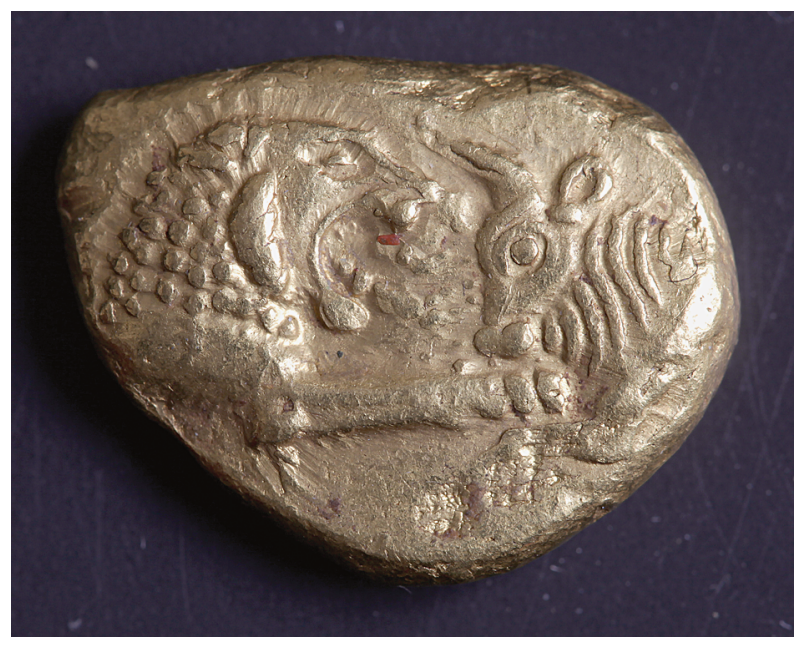

Fig. 17. "Croeseid" coin from Sardis (IAM 8947), part of the hoard found in 1922. (Courtesy of Yapı Kredi Bankası, Vedat Nedim Tör Müzesi)

closest iconographic parallel to this couchant mixed creature with lion-like characteristics and an ibex's horn is to be found in a later seal excavated from Sardis, IAM 4641 (Curtis 1925: no. 109) (Figs. 18, 19). ${ }^{23}$ This chalced-

glyptic motif assimilated into numismatic iconography. The segmented horn of the ibex is shown in an almost geometric style in a bracteate from Ziwiye (Francfort 2013: fig. 23). Contrast the fluid style of the ibex's horn on the coins of, e.g., the early electrum coins of Miletus (Weidauer 1975: nos. 11, 12) or Achaemenid-period Kelenderis (Casabonne 2000: pl. 17, no. 7)-but note that that animal's ear is rendered with two delicate lines coming to a tip in a manner that is similar to that of the Sardis seal.

${ }^{23}$ Heraldic, seated, human-headed, ibex-horned, lion-bodied sphinxes on a cylinder seal of the mid-5th century are found impressed 


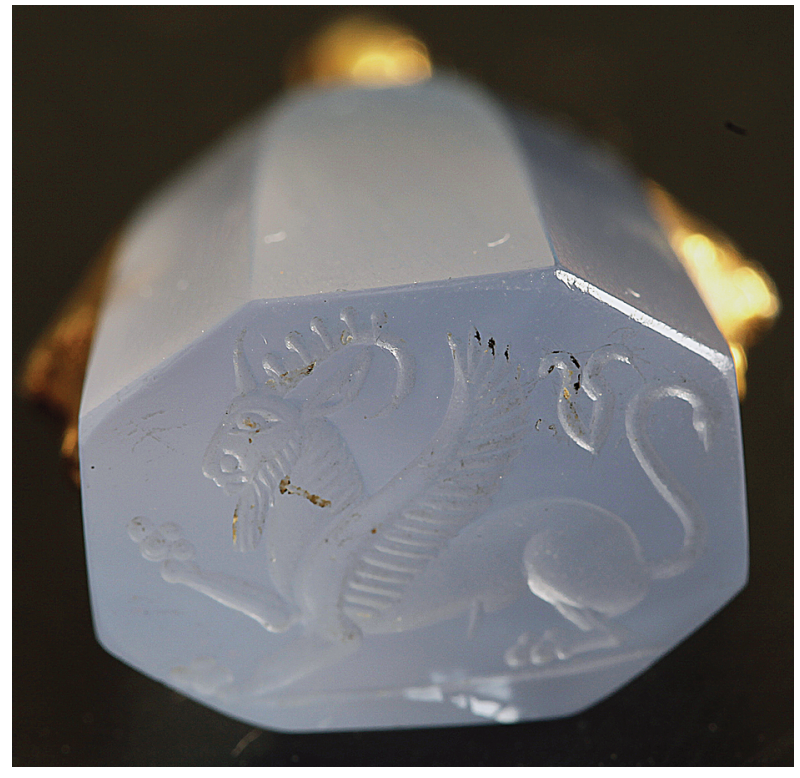

Fig. 18. Achaemenid seal from Sardis (IAM 4641). (Courtesy of Yap1 Kredi Bankası, Vedat Nedim Tör Müzesi)

ony pyramidal stamp seal with a gold suspension device formed in the shape of ducks' heads preserves a humanheaded, winged lion with wild-goat horns. Perhaps, the combination of elements had some specific Sardian cultural resonance we cannot now recover.

\section{What Did It Mean To Be Lydian?}

The unique creature on the seal from Sardis, with its myriad ties to the iconographic ideas of the Aegean, Anatolia, Syria, Assyria, and Phoenicia, fits very well with an understanding of Lydian artistic creativity gained from other portrayals of animals at Sardis in the years just preceding the Achaemenid conquest of the site. An unfinished bronze bridle attachment in the form of an ibex with its head reverted combines the formidable swoop of the animal's horn with a delicate, almost tender rendition of its body and enormous soft eye in a manner simultaneously virtuosic and evocative (Greenewalt 2010a: fig. 11, no. 49; see also a Samian version in Walter-Karydi 1973: pl. 47, no. 422). Ivory chapes excavated from the HoB

on the Persepolis Treasury tablets (see Schmidt 1957: PTS 40) and on an Achaemenid pyramidal stamp seal impressed on the Daskyleion bullae (see Kaptan 2002: DS 44.1). They are also found on an Achaemenid pyramidal stamp seal from Damascus, now in Berlin (JakobRost 1997: no. 481). The Persepolis Fortification Archive tends to have human-faced, ibex-horned, winged, bull-bodied creatures rather than lion-bodied ones; none of the human-headed lion-bodied creatures on the Fortification Archive tablets has horns.

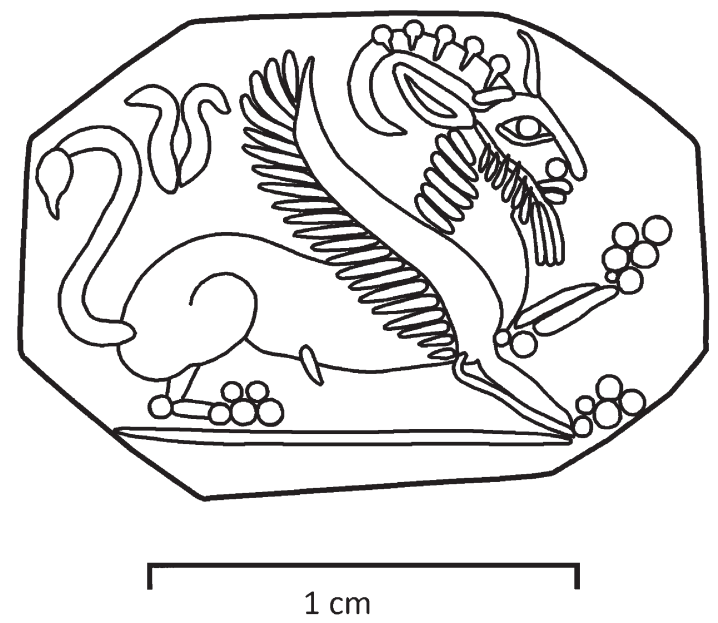

Fig. 19. Drawing of impression of IAM 4641. (Drawing by E. R. M. Dusinberre)

sector at Sardis were carved with animals in "nomadic" style (Cahill 2010b: nos. 54, 55). The lions of Lydian orientalizing pottery of the mid-6th century clearly took their inspiration from Phrygian and Neo-Hittite prototypes, and with their knobby lower jaws and prominent tongues recall the creature on the seal (e.g., Greenewalt 2010b: fig. 12, no. 90). But the particular unique whimsy of Lydian artists is evident in many portrayals of animals, whether that be the great snaky-bodied sea monsters on a painted lebes, a boat-shaped vessel with two horses' heads for handles, or a side-spouted vase shaped like a duck with its head turned to the left so that it might watch the user drink from its spout. ${ }^{24}$

The seal from Sardis thus adds to our understanding of the kinds of multicultural interactions that characterized Lydian Sardis. Gül Gürtekin-Demir has recently demonstrated the ways in which Lydian potters embraced aspects of Phrygian ceramic production and culture, incorporating aspects of Phrygian notions into Lydian creations even as they adapted them into wholly different expressions and combinations at Sardis (GürtekinDemir 2014). This little seal shows that a similar creative zest, fueled by the expressive capacity and options of the many different groups of people with whom the Lydians were in contact, characterized the glyptic artists of Sardis in the Lydian period. The seal is unique and entirely at home in the plurality of opportunities at play in Sardis during the age of Croesus.

${ }^{24}$ For the boat-shaped vase with horse heads, see Greenewalt 2010a; 2010b: no. 70. For the lebes, see Greenewalt 2010b: fig. 13, no. 71. For the duck vase, see no. 86 . 


\section{Acknowledgments}

I am grateful to Nick Cahill for inviting me to study this artifact, and to Cahill and Margaret Cool Root for their extensive comments on a draft. Thanks also to the two anonymous reviewers for BASOR who provided most helpful comments and suggestions. I am also grateful to Cahill, Andrea Berlin, and Will Bruce for lengthy discussions at Sardis about stratigraphy and interpretation of the seal's context. Many thanks to the
Sardis Office and its outstanding personnel for assistance with images, notes, and more. Thanks to the Ministry of Culture and Tourism of the Republic of Turkey and to the General Directorate of Museums for permission to work on the seal, and to the staff of the Manisa Museum and its director, Sevgi Soyaker, for making my time there so productive and pleasant. Any flaws remaining are my own.

\section{References}

Bellinger, A.

1968 Electrum Coins from Gordion. Pp. 10-15 in Essays in Greek Coinage Presented to Stanley Robinson, ed. C. M. Kraay and K. Jenkins. Oxford: Clarendon.

Boardman, J.

1970 Pyramidal Stamp Seals in the Persian Empire. Iran 8: 19-45.

Bodenstedt, F.

1981 Die Elektronmünzen von Phokaia und Mytilene. Tübingen: Wasmuth.

Buzzi, S.

1999 Die architektonischen Terrakotten aus Düver: Der Archäologischen Sammlung der Universität Zürich. Archäologische Sammlung der Universität Zürich Sammlungskataloge 2. Zurich: Archäologisches Institut der Universität Zürich.

Cahill, N. D.

2000 Lydian Houses, Domestic Assemblages, and Household Size. Pp. 173-85 in Across the Anatolian Plateau: Readings in the Archaeology of Ancient Turkey, ed. D. C. Hopkins. Annual of the American Schools of Oriental Research 57. Boston: American Schools of Oriental Research.

2005 Household Industry in Greece and Anatolia. Pp. 54-66 in Ancient Greek Houses and Households: Chronological, Regional, and Social Diversity, ed. B. A. Ault and L. C. Nevett. Philadelphia: University of Pennsylvania Press.

2010a Functional Analyses of Ancient House Inventories. Pp. 477-95 in Städtisches Wohnen im östlichen Mittelmeerraum 4. Jh. v. Chr.-1. Jh. n. Chr.: Akten des Internationalen Kolloquiums vom 24.-27. Oktober 2007 an der Österreichischen Akademie der Wissenschaften, ed. S. Ladstätter and V. Scheibelreiter. Denkschriften der philosophisch-historischen Klasse 397; Archäologische Forschungen 18. Vienna: Austrian Academy of Sciences.

2010b Sardis, 2008. Kazı Sonuçları Toplantısı 31 (4): 63-74.

2011 Sardis, 2009. Kazı Sonuçları Toplantısı 32 (3):358-67.

2012 Sardis, 2010. Kazı Sonuçları Toplantısı 33 (4): 209-29.

2013 Sardis, 2011. Kazı Sonuçları Toplantısı 34 (2): 147-60.

2014 Sardis, 2012. Kazı Sonuçları Toplantısı 35 (3): 119-35.

2015 Sardis, 2013. Kazı Sonuçları Toplantısı 36 (2): 413-30.
Cahill, N. D., ed.

2010 Lidyalılar ve Dünyaları [The Lydians and Their World]. Yapı Kredi Kültür Yayınları 3055. Istanbul: Yapı Kredi Yayınları.

Cahill, N. D., and Kroll, J. H.

2005 New Archaic Coin Finds at Sardis. American Journal of Archaeology 109: 589-617.

Casabonne, O., ed.

2000 Mécanismes et innovations monétaires dans l'Anatolie achéménide: Numismatique et histoire; Actes de la table ronde international d'Istanbul, 22-23 Mai 1997. Varia Anatolica 12. Istanbul: Institut français d'études anatoliennes; Paris: Boccard.

Collins, B. J.

2002 Animals in the Religions of Ancient Anatolia. Pp. 309-34 in A History of the Animal World in the Ancient Near East, ed. B. J. Collins. Handbook of Oriental Studies 1, The Near and Middle East 64. Leiden: Brill.

Collon, D.

1993 A Hoard of Sealings from Ur. Pp. 65-84 in Archives et sceaux du monde hellénistique, Torino, Villa Gualino, 13-16 gennaio 1993, ed. M.-F. Boussac and A. Invernizzi. Bulletin de correspondance hellénique Supplement 29. Athens: École française d'Athènes.

2001 How Seals Were Worn and Carried: The Archaeological and Iconographic Evidence. Pp. 15-30 in Seals and Seal Impressions, ed. W. W. Hallo and I. J. Winter. Proceedings of the XLVe Rencontre assyriologique internationale 2. Bethesda, MD: CDL.

Cook, R. M., and Dupont, P.

1998 East Greek Pottery. Routledge Readings in Classical Archaeology Series. London: Routledge.

Curtis, C. D.

1925 Sardis XIII: Jewelry and Gold Work, Part 1: 19101914. Rome: Sindacato italiano arti grafiche.

Draycott, C. M., and Summers, G. D.

2008 Sculpture and Inscriptions from the Monumental Entrance to the Palatial Complex at Kerkenes Dăg, Turkey. Oriental Institute Publications 135; Kerkenes Special Studies 1. Chicago: Oriental Institute of the University of Chicago. 
Dusinberre, E. R. M.

1997 Imperial Style and Constructed Identity: A "Graeco-Persian" Cylinder Seal from Sardis. Ars Orientalis 27: 99-129.

2003 Aspects of Empire in Achaemenid Sardis. Cambridge: Cambridge University Press.

2005 Gordion Seals and Sealings: Individuals and Society. University Museum Monograph 124; Gordion Special Studies 3. Philadelphia: University of Pennsylvania Museum of Archaeology and Anthropology.

2008 Circles of Light and Achaemenid Hegemonic Style in Gordion's Seal 100. Pp. 87-98 in Love for Lydia: A Sardis Anniversary Volume Presented to Crawford H. Greenewalt, Jr., ed. N. D. Cahill. Archaeological Exploration of Sardis Monographs 4. Cambridge, MA: Harvard University Press.

2010a Anatolian Crossroads: Achaemenid Seals from Sardis and Gordion. Pp. 323-35 in The World of Achaemenid Persia: Diversity of Ancient Iran, ed. J. E. Curtis and S. J. Simpson. London: Tauris.

2010b Lydo-Persian Seals from Sardis. Pp. 177-90 in Lidyalılar ve Dünyaları [The Lydians and Their World], ed. N. D. Cahill. Yapı Kredi Kültür Yayınları 3055. Istanbul: Yapı Kredi Yayınları.

2013 Empire, Authority, and Autonomy in Achaemenid Anatolia. Cambridge: Cambridge University Press.

Fitton, J. L.

1992 Ivory in Greece and the Eastern Mediterranean from the Bronze Age to the Hellenistic Period. British Museum Occasional Paper 85. London: British Museum Press.

Francfort, H.-P.

2013 L'art oublié des lapidaires de la Bactriane aux époques achéménide et hellénistique. Persika 17. Paris: Boccard.

Garrison, M. B., and Root, M. C.

Forth- Sealson the Persepolis Fortification Tablets, Vol.3: Ani-

coming mals, Creatures, Plants, and Geometric Devices. Chicago: Oriental Institute of the University of Chicago.

Greenewalt, C. H., Jr.

1970 Orientalizing Pottery from Sardis: The Wild Goat Style. California Studies in Classical Antiquity 3: 55-89.

1971 Fikellura and "Early Fikellura" Pottery from Sardis. California Studies in Classical Antiquity 4: 153-80.

1973 "Ephesian Ware." California Studies in Classical Antiquity 6: 91-122.

1992 When a Mighty Empire Was Destroyed: The Common Man at the Fall of Sardis, ca. 546 B.c. Proceedings of the American Philosophical Society 136: 247-71.

2008 Sardis: Archaeological Research and Conservation Projects in 2006. Kazı Sonuçları Toplantısı 29 (3): 371-86.

2009 Sardis: Archaeological Research and Conservation Projects in 2007. Kazı Sonuçları Toplantısı 30 (4): 191-204. 2010a Introduction. Pp. 7-36 in Lidyalılar ve Dünyaları [The Lydians and Their World], ed. N. D. Cahill. Yap1 Kredi Kültür Yayınları 3055. Istanbul: Yap1 Kredi Yayınları.

2010b Lydian Pottery. Pp. 107-24 in Lidyalılar ve Dünyalart [The Lydians and Their World], ed. N. D. Cahill. Yapı Kredi Kültür Yayınları 3055. Istanbul: Yapı Kredi Yayınları.

Greenewalt, C. H., Jr.; Cahill, N. D.; Dedeoğlu, H.; and Herrmann, $\mathrm{P}$.

1990 The Sardis Campaign of 1986. BASOR Supplement 26: 137-77.

Greenewalt, C. H., Jr.; Cahill, N. D.; and Rautman, M. L.

1988 The Sardis Campaign of 1984. BASOR Supplement 25: $13-54$.

Greenewalt, C. H., Jr.; Rautman, M. L.; and Cahill, N. D.

1988 The Sardis Campaign of 1985. BASOR Supplement 25: 55-92.

Greenewalt, C. H., Jr.; Rautman, M. L.; and Ratté, C.

1995 The Sardis Campaigns of 1992 and 1993. Pp. 1-36 in Preliminary Excavation Reports: Sardis, Idalion, and Tell el-Handaquq North, ed. W. G. Dever. Annual of the American Schools of Oriental Research 53. Atlanta: Scholars.

Greenewalt, C. H., Jr.; Sullivan, D. G.; Ratté, C.; and Howe, T. N.

1985 The Sardis Campaigns of 1981 and 1982. BASOR Supplement 23: 53-92.

Gürtekin-Demir, R. G.

2007 Provincial Production of Lydian Painted Pottery. Pp. 41-48 in Anatolian Iron Ages 6: The Proceedings of the Sixth Anatolian Iron Ages Colloquium Held at Eskişehir, 16-20 August 2004, ed. A. Çilingiroğlu and A. Sagona. Ancient Near Eastern Studies Supplement 20. Leuven: Peeters.

2010 A Small Group of Pottery with Lydian Character from Gavurtepe, Alaşehir. Arkeoloji Dergisi 15: 41-48.

2011 An Eastern Mediterranean Painting Convention in Western Anatolia: Lydian Black-on-Red. Pp. 359-78 in Intercultural Contacts in the Ancient Mediterranean: Proceedings of the International Conference at the Netherlands-Flemish Institute in Cairo, 25th to 29th October 2008, ed. K. Duistermaat and I. Regulski in collaboration with G. Jennes and L. Weiss. Orientalia Lovaniensia Analecta 202. Leuven: Peeters.

2014 Phrygian Aspects of Lydian Painted Pottery from Sardis. American Journal of Archaeology 118: 223-39.

Hanfmann, G. M. A.

1966 The Eighth Campaign at Sardis (1965). Bulletin of the American Schools of Oriental Research 182: 2-54.

1967 The Ninth Campaign at Sardis (1966). Bulletin of the American Schools of Oriental Research 186: 17-52.

Head, B. V.

1964a A Catalogue of the Greek Coins in The British Museum, Vol. 14: Catalogue of the Greek Coins of Ionia. Bologna: Forni. 
1964b A Catalogue of the Greek Coins in The British Museum, Vol. 22: Catalogue of the Greek Coins of Lydia. Bologna: Forni.

Herbordt, S.

1992 Neuassyrische Glyptik des 8.-7. Jh. v. Chr. State Archives of Assyria Studies 1. Helsinki: Neo-Assyrian Text Corpus Project.

Herrmann, H.-V.

1979 Die Kessel der orientalisierenden Zeit. Olympische Forschungen 11. Berlin: De Gruyter.

Hostetter, E.

1994 Lydian Architectural Terracottas: A Study in Tile Replication, Display and Technique. Archaeological Exploration of Sardis. Illinois Classical Studies Supplement 5. Atlanta: Scholars.

Jakob-Rost, L.

1997 Die Stempelsiegel im Vorderasiatischen Museum. Mainz: Zabern; Berlin: Staatliche Museen zu Berlin, Vorderasiatisches Museum.

Jantzen, U.

1955 Griechische Greifenkessel. Berlin: Mann.

Kaptan, D.

2002 The Daskyleion Bullae: Seal Images from the Western Achaemenid Empire. Achaemenid History 12. Leiden: Netherlands Institute for the Near East.

Kardara, C.

1963 Rhodiake Aggeiographia. Athens: Athenian Archaeological Society.

Keel-Leu, H.

1991 Vorderasiatische Stempelsiegel: Die Sammlung des Biblischen Instituts der Universität Freiburg Schweiz. Orbis Biblicus et Orientalis 110. Fribourg: Universitätsverlag; Göttingen: Vandenhoeck \& Ruprecht.

Kerschner, $\mathrm{M}$.

2007 Das Keramikbild von Ephesos im 7. und 6. Jh. v. Chr. Pp. 221-45 in Frühes Ionien: Eine Bestandsaufnahme: Panionion-Symposion, Güzelçaml, 26. September-1. Oktober 1999, ed. J. Cobet, V. von Graeve, W.-D. Niemeier, and K. Zimmermann. Milesische Forschungen 5. Mainz: Zabern.

Kraay, C. M.

1976 Archaic and Classical Greek Coins. Library of Numismatics. Berkeley: University of California Press.

Kroll, J. H.

2010 The Coins of Sardis. Pp. 143-56 in Lidyalılar ve Dünyaları [The Lydians and Their World], ed. N. D. Cahill. Yapı Kredi Kültür Yayınları 3055. Istanbul: Yapı Kredi Yayınları.

Legrain, L.

1951 Seal Cylinders. Ur Excavations 10. Philadelphia: University Museum, University of Pennsylvania; London: British Museum.

Luke, C., and Roosevelt, C. H.

2009 For Sale from "East Greece" or "Persia": Lydia and the Antiquities Market. Paper presented at the American Institute of Archaeology annual meeting, Philadelphia, PA.
Matthews, D. M.

1990 Principles of Composition in Near Eastern Glyptic of the Later Second Millennium B.C. Orbis Biblicus et Orientalis, Series Archaeologica 8. Fribourg: Universitätsverlag; Göttingen: Vandenhoeck \& Ruprecht.

Mayo, M. E.

1981 Architectural Terra Cotta from Phrygia. Arts in Virginia 21 (2): 28-35.

Mitchell, T. C., and Searight, A.

2007 Catalogue of the Western Asiatic Seals in The British Museum, Stamp Seals III: Impressions of Stamp Seals on Cuneiform Tablets, Clay Bullae, and Jar Handles. Leiden: Brill.

Orthmann, W.

1971 Untersuchungen zur späthethitischen Kunst. Saarbrücker Beitragen zur Altertunskunde 8. Bonn: Habelt.

Özgen, İ., and Öztürk, J.

1996 Heritage Recovered: The Lydian Treasure. Istanbul: General Directorate of Monuments and Museums, Ministry of Culture, Republic of Turkey.

Prayon, F.

1987 Phrygische Plastik: Die früheisenzeitliche Bildkunst Zentral-Anatoliens und ihre Beziehungen zu Griechenland und zum Alten Orient. Tübinger Studien zur Archäologie und Kunstgeschichte 7. Tübingen: Wasmuth.

Ramage, A.

1978 Lydian Houses and Architectural Terracottas. Archaeological Exploration of Sardis. Cambridge, MA: Harvard University Press.

Ramage, N. H.

1983 A Merrythought Cup from Sardis. American Journal of Archaeology 87: 453-60.

1986 Two New Attic Cups and the Siege of Sardis. American Journal of Archaeology 90: 419-24.

Rein, M. J.

1993 The Cult and Iconography of Lydian Kybele. Ph.D. dissertation, Harvard University.

Reyes, A. T.

2001 The Stamp-Seals of Ancient Cyprus. University of Oxford, School of Archaeology Monographs 52. Oxford: School of Archaeology, University of Oxford.

Roller, L. E.

2009 The Incised Drawings from Early Phrygian Gordion. University Museum Monographs 130; Gordion Special Studies 4. Philadelphia: University of Pennsylvania Museum of Archaeology and Anthropology.

Roosevelt, C. H., and Luke, C.

2006a Looting Lydia: The Destruction of an Archaeological Landscape in Western Turkey. Pp. 173-87 in Archaeology, Cultural Heritage, and the Antiquities Trade, ed. N. Brodie, M. M. Kersel, C. Luke, and K. W. Tubb. Cultural Heritage Studies. Gainesville: University of Florida Press. 
2006b Mysterious Shepherds and Hidden Treasures: The Culture of Looting in Lydia. Journal of Field Archaeology 31: 185-98.

Root, M. C.

2002 Animals in the Art of Ancient Iran. Pp. 169-209 in A History of the Animal World in the Ancient Near East, ed. B. J. Collins. Handbook of Oriental Studies 1, The Near and Middle East 64. Leiden: Brill.

Schachner, A.

2014 Beobachtungen zu den Siegeln und Kleinfunden der Eisenzeit vom Dülük Baba Tepesi (2010-2012). Pp. 33-48 in Kult und Herrschaft am Euphrat, ed. E. Winter. Dolichener und Kommagenische Forschungen 6; Asia Minor Studien 73. Bonn: Habelt.

Schaeffer, J. S.; Ramage, N. H.; and Greenewalt, C. H., Jr.

1997 The Corinthian, Attic, and Lakonian Pottery from Sardis. Archaeological Exploration of Sardis. CamSchmidt, E. F. bridge, MA: Harvard University Press.

1957 Persepolis II: Contents of the Treasury and Other Discoveries. Oriental Institute Publications 69. Chicago: University of Chicago.

Wagner, C., and Boardman, J.

2003 A Collection of Classical and Eastern Intaglios, Rings and Cameos. Studies in Gems and Jewellery 1; BAR International Series 1136. Oxford: Archaeopress.
Wallace, R. W.

2006 KUKALIM, WALWET, and the Artemision Deposit: Problems in Early Anatolian Electrum Coinage. Pp. 37-48 in Agoranomia: Studies in Money and Exchange Presented to John H. Kroll, ed. P. G. van Alfen. New York: American Numismatic Society.

Walter-Karydi, E.

1968 Corpus Vasorum Antiquorum: Deutschland, Vol. 28: München, Museum Antiker Kleinkunst, Part 6. Munich: Beck.

1973 Sämische Gefässe des 6. Jahrhunderts v. Chr.: Landschaftsstile ostgriechischer Gefässe. Samos 6 (1). Bonn: Habelt.

Weidauer, L.

1975 Probleme der frühen Elektronprägung. Typos 1. Fribourg: Office du Livre.

Young, R. S.

1956 The Campaign of 1955 at Gordion: Preliminary Report. American Journal of Archaeology 60: 249-66.

1964 The 1963 Campaign at Gordion. American Journal of Archaeology 68: 279-92. 